\title{
Residents' Perception and Response to Development Control Activities in Nigerian Cities: The Case of Ibadan and Akure, South-West, Nigeria
}

\author{
Agbonta W. A. P. ${ }^{1, *}$ and Olowoporoku O. A. ${ }^{2}$ \\ ${ }^{1}$ Department of Architecture, University of Benin, Benin City, Nigeria \\ ${ }^{2}$ Department of Urban and Regional Planning, Obafemi Awolowo University, Ile-Ife, Nigeria \\ Corresponding Author: *wilson.agbonta@uniben.edu
}

\begin{abstract}
This study assessed residents' perception and response to development control activities in Ibadan and Akure Nigeria. This was with a view to suggesting policy a response capable of enhancing orderly control of development in the cities and others with similar background. A local government was selected in each of the two cities. This is followed by the selection of two wards in each of the selected local governments across the two cities. In the four selected wards, every 20th residential building was sampled sequel to listing of buildings based on street numbering system and counting of buildings where houses were not numbered. For the study, 106 residents were sampled on whom questionnaires were administered. This sample comprised 55 respondents in Ibadan and 51 residents in Akure. Data analysis was done using descriptive statistics. Findings revealed that demolition exercise was the major source of awareness of development control activities across the two cities. However, there were differences in residents' perception of roles of development control agencies in Ibadan and Akure. The study also found that majority of the residents across the two cities do not have survey plans neither do they prepare building plans before embarking on construction. This study established the divergent views on satisfaction with conduct of development control activities among residents of Ibadan and Akure. The study recommended that development control agencies in the two cities should cultivate a cordial relationship with the residents in order to motivate them to fulfil land administration requirements before embarking on construction exercises.
\end{abstract}

Keywords: Development control, physical planning, residents, urbanization, urban centres

\subsection{Introduction}

Urban centres throughout the world exhibit an incredible diversity of characteristics, economic, structure, levels of infrastructure, historical origins, patterns of growth and degree of formal planning (Amujiri, 2001; Agbola, 2007; UN-Habitat, 2009). The process of urbanization has become more rapid and massive, thus posing a challenge to a greater part of the world than ever before (Alabi, 2010; Fabiyi, 2006). Studies such as Bhata (2010), Oyelade, (2012), Adeyemi (2014) and UN-HABITAT (2016) have established that population upsurge in cities account for lateral expansion, structural growth of settlement and associated problems. Lateral growth occurs when the city expands in geographical boundaries. In essence, the issue of agglomeration of population into urban areas leads to the quest for more development on land to commensurate with the demographic structure.

The state of the physical environment particularly in the urban centres today is a major source of global concern (Kawu,, Ahmed, and Usman, 2012). Most land users in the developing world in their quest for development carried out their activities without recourse to planning agencies for planning approval and strict adherence to planning standards thereby contravening existing planning laws related to development (Oduwaye 2004; Olujimi and Fashuyi, 2004; Obabori, Obiwuevi and Olomu, 2007; Aluko, 2010). Physical development often has severe impacts on the environmental components such as land, water and air. The concern is greater in respect of developing nations like Nigeria. This justifies a need for proper physical planning in attaining sustained control and development of the environment. Urban planning involves organized legal activities that are directed towards spatial ordering of land uses in order to create a functional and healthy physical environment for living, working and recreating 
(Lamond, Awuah, Lewis, Bloch and Falade, 2015). It provides a framework for building and managing the environment. One of the veritable ways of carrying out urban planning is development control. Adeyeye (2010) defined development control as a physical planning instrument which generally involves the regulation, restraining and keeping in order or checking material change to land. In another parlance it is a strong and effective tool of urban planning and management (Vivan, Kyom and Balasom, 2013). Development control is a way of checking and regulating development of land by planning authorities (Obabori et al, 2007). Development control policies are aimed to ensure coordination and compatibility of land uses to bring about improvement in the general welfare of a people (Sanusi, 2006). The cumulative effect of the urbanization process is seen in the haphazard spatial development, the attendant problems of congestion, the inaccessibility to some activity areas, pollution, slum formation, rising costs of land, accessibility to urban land for land housing, incompatible use, flooding, overcrowding and congestion, housing famine, environmental chaos and other forms of environmental degradation (Kio-Lawanson, Duru, John and Eebee, 2016). Development control activities in Nigeria are domiciled in land administration agencies ranging from federal to local government levels. Till date, development control has been applied in Nigeria through series of Acts, Laws and Policies. These include the Land Use Act of 1978, Urban Development Policy of 1992, the Urban and Regional Planning Decree of 1998 as well as the Housing and Development Policy of 2002. Despite the existence of these laws and policies, development control problems still persist in the country.

The persistence of uncontrolled expansion of Nigerian cities has forced planners and stakeholders to accept that development control has failed (Agboola, 2007). The high rate of urbanization of physical environmental problems which characterized urban centres in Nigeria is an indication that development control mechanisms in the country have been ineffective. The effects of these problems are development of illegal structures in urban centres. Issues pertaining to development control activities have attracted the interest of researchers in Nigeria. Several studies have advocated for strengthening the effectiveness of the exercise through better enforcement of the law. These studies include Omisore and Akande (2004), Aribigbola (2008), Olotuah, (2010) and Ogundele et al (2011). Others studies that have examined the practice of development control activities in the country Oduwaye, (2004), Olujimi (2009), Ujoh and Ifatimehin, (2010), Kawu, Ahmed and Usman, (2012), Vivian, Kyom and Balasom (2013).

These researches have highlighted the concept, relevance and problems associated with development control in Nigeria. They have also examined the uses of various development control tools as well as development control mechanisms for producing conducive, aesthetically pleasing, functional, safe and more importantly healthy environment for all Nigerians. As relevant as these studies could be in ensuring the effectiveness of development control activities in Nigerian cities, a major setback is their little emphasis on the perception of the people on development control. The views of the residents, who are the major stakeholders in ensuring the success of the development control exercise, have been less considered in literature. It has been established that residents' perception data can be used as a tool in proffering solution to different problems in different areas of human endeavour (Afon, Abolade and Okanlawon, 2006). In this era of participatory approach to urban issues, the need for residents' perception in the quest for effective development control cannot be jettisoned.

Information from perception studies guides policy makers in adopting bottom-up approach, leading to decision making that will be acceptable to the people at a particular time. Understanding residents' perception of development control activities will be a successful instrument to ensure full citizen involvement in the exercise. It can be used to know the attitude of residents to particular aspects of the programme. For the success of any physical planning activity information about peoples' perception on physical development agencies are very imperative. This type of investigation is very imperative as the role of citizen participation in the success of development control activity cannot be underestimated. The thrust of this paper, therefore, is to examine residents' perception of development control activities in Ibadan and Akure, Nigeria. In achieving this, the study examined the socio-economic characteristics of the residents and their opinion on the effectiveness of development control activities in the study area. 


\subsection{Materials and Methods}

\subsection{Study Area}

The study area is Akure, the administrative capital of Ondo State. Akure became the state capital of Ondo State in 1976. The town is located within $7^{0} 15^{\prime}$ North of the Equator and Longitude $5^{0} 05^{\prime}$ East of the Greenwich Meridian. It is about 204km east of Ibadan, capital of Oyo state; $168 \mathrm{~km}$ west of Benin City, capital of Edo state; $311 \mathrm{~km}$ north-east of Lagos; and $323 \mathrm{~km}$ south-west of Abuja, the Federal Capital Territory of Nigeria. The city spreads over an area of about $15,500 \mathrm{~km} 2$ in about $370 \mathrm{~m}$ above the sea level (Owoeye and Adedeji, 2003) Its population figure of the city by the National Population Census of 1963 was just 71,106. With the influx of public servants into the town consequently upon state creation in 1976, the population rose to 239,124 and 360,268 in 1991 and 2006, respectively, with a projection of 476,159 in the year 2014 (Owoeye and Ibitoye, 2016). The increased relative political influence of Akure as a State capital since 1976, when Ondo State was created has been partly responsible for its rapid development. This is because, the decentralization exercise, which accompanied the policy that led to the creation of the State led to the creation of jobs, which attracted many people. The multifarious activities, performed by Akure, influence the desire to construct new roads and rehabilitate the old ones to take care of the envisaged new roles and status of the city.

Ibadan is currently the capital city of Oyo State; one of the 36 States of Nigeria. It is located approximately on latitude $7^{0} 22^{\prime}$ and $7^{0} 40^{\prime}$ North of the Equator and $3^{0} 53^{\prime}$ and $4^{0} 10^{\prime}$ East of the Greenwich Meridian. It is Nigeria's second-largest urban agglomeration, with a population of about 3.3 million people (Oyelayo, 2014). It is centrally situated in the South-western sector of the country. Ibadan comprises of eleven local government areas. Administratively, Ibadan Metropolis consists of five local government areas; the inner city. These are Ibadan North, Ibadan North East, Ibadan North West, Ibadan South East and Ibadan South West. The peculiarity of these five areas is that they converge at a point, Mapo hill. The remaining six local government areas constitute the suburbs of the metropolis. Spatially, Ibadan sprawls over a radius of 12-15 km (Afon and Faniran, 2012; Fakere, Fadairo and Oriye, 2012). The city is facing serious environmental issues relating to its high rate of urbanisation accompanied by acute shortage of water supply and poor management of solid and liquid wastes (Oyelayo, 2014).

The basis for selection of the cities were to compare residents' perception to development control activities between older generation city (capital cities as at independence of Nigeria) and cities named after independence of Nigeria.

\subsection{Field Survey and Analysis Method}

This study was based on a field survey through administration of questionnaire. The sampling procedure started with a focus on the two capital cities. One local government was selected in each of the capital cities. Two wards were selected in each of the local government area selected. A total of four political wards were selected for survey. In the two political wards selected in Ibadan, reconnaissance survey revealed that 1120 buildings while in the two political wards selected in Akure, there are 1020 residential buildings. One out of every 20th residential building identified was sampled sequel to listing of buildings based on street numbering system and counting of buildings where houses were not numbered in each of the cities. In each of the selected residential buildings, the target respondents were the household heads.

For the study, 106 residents were sampled on which questionnaires were administered. This sample comprised 55 respondents in Ibadan and 51 residents in Akure. One out of every twenty buildings was selected and questionnaire was administered on an adult residing in each of the selected buildings across the selected wards. Issues addressed in the questionnaire included socioeconomic attributes of the residents and those pertaining to residents' perception and response to development control activities in their cities. The questionnaire was designed to seek the opinion of the residents on the level of 
agreement/disagreement with functions of development control agencies on a 5- point Likert scale using 1 for strongly disagreed (SD), 2 for disagreed (DA), 3 for neutral (N), 4 for agreed (A) and 5 for strongly agreed (SA). Residents' opinion on satisfaction/dissatisfaction with development control activities was rated on a 5- point Likert scale using 1 for strongly unsatisfied (SUS), 2 for unsatisfied (US), 3 for neutral (N), 4 for satisfied (S) and 5 for strongly satisfied (SS). Analysis of the data was done using cross tabulation and mean.

Mean index was used to analyse residents level of agreement with functions of development control agencies and satisfaction with development control activities in the study area. The analysis of the responses evolved 'Residents' Agreement Indexes" (RAI) and mean Residents' Agreement Indexes' $(\overline{\mathrm{RAI}})$. To obtain a RAI, a weighted value of $5,4,3,2$ and 1 were respectively attached to rate each response $(\mathrm{SA}=5, \mathrm{~A}=4, \mathrm{~N}=3, \mathrm{DA}=2$ and $\mathrm{SD}=1)$ on any of the functions. The RAI for each item was obtained through the sum of the product of number of responses of each item and the respective weighted value attached to each rating. This is expressed mathematically as:

$$
\mathrm{SWV}=\sum_{I=1}^{5} X_{i} Y_{i}
$$

where SWV = summation of weight value, $X_{i}=$ number of respondents to rating $i$, and $Y_{i}=$ the weight assigned a value $(\mathrm{i}=1,2,3,4,5)$.

The RAI for each item on the scale was arrived at by dividing the Summation of Weighted Value (SWV) by the total number of respondents $(\mathrm{N}=55)$ and $(\mathrm{N}=51)$ for Ibadan and Akure respectively, mathematically expressed as:

$\mathrm{RAI}=\frac{\mathrm{swV}=\sum_{I=1}^{5} X_{i} Y_{i}}{N}$

The $\overline{\mathrm{RAI}}$ later was computed by summing the total number of RAI and dividing by the number of the identified functions of development control agencies $(n=15)$, mathematically expressed as:

$\overline{\mathrm{RAI}}=\frac{\mathrm{RAI}}{n}$

Any RAI with actual value of the $\overline{\mathrm{RAI}}$ indicated a moderate level of agreement of functions of development control agencies by household heads. Values with positive deviations indicated high level of agreement while those with negative deviations indicated low level of agreement of the function of development control agencies by household heads. The ranks of the index values were likewise provided.

Deviation about the Mean Residents Agreement Index (RAI- $\overline{\mathrm{RAI}}$ ) for each of the Residents Agreement Indexes was later computed. The deviations were only representative measures of dispersion that provided information on either agreement or disagreement with the functions of development control agencies as perceived by the residents. The variables with positive deviations had high level of agreement while those with negative deviations indicated low level of agreement. For more understanding of the dispersion of the distribution about the mean indexes, the standard deviation (SD) for each city was computed. The standard deviation measured the degree of spread or dispersion of the level of agreement with the functions of development control agencies within the same distribution. A small value of the standard deviation indicated that RAIs clustered around the $\overline{\text { RAI }}$. In further establishing the above fact and also ascertaining the reliability of the $\overline{\mathrm{RAI}}$ based on the data distribution for each of the cities, the Coefficient of Variation (CV) for each city was computed.

Respondents' satisfaction with the activities of development control agencies was measured through an index called Residents Severity Indexes RSI. The procedure of arriving at this indexes is similar to the one used to measure Residents Agreement Indexes (RAI). 


\subsection{Results and Discussion}

\subsection{Socioeconomic and Housing Attributes of Residents}

In this study, findings were made on the socioeconomic and housing characteristics of residents that could influence their perception and response to development control activity. The variables discussed in this regard are gender, age, educational status, income, length of residence and type of building. These identified factors of perception in literature, and by extension, perception of development control exercise are discussed to provide descriptive information on the personal and social aspects of the respondents (Afon, 2011; Daramola 2015; Daramola and Olowoporoku, 2016; Odunsi, 2016; Olowoporoku, 2017a).

The frequency distribution of these variables across Ibadan and Akure is presented in Table 1 . The study revealed that, in Ibadan, $41.8 \%$ of the respondents were male while $58.2 \%$ were female. In Akure, the male respondents comprised $64.7 \%$ of the total of 51 respondents while the remaining $35.3 \%$ were female. This gender distribution will afford the study to have perceptions based on gender differential. Also, majority of the respondents (70.9\%) in Ibadan were between age of 20 and 60 years. The case was similar in Akure with $78.4 \%$ of the residents aged 20 to 60 years while $21.6 \%$ of the remainder were more than 60 years. These findings indicate that the residents were of age to give reliable information on development control activities. The mean ages in Ibadan and Akure were 53 years and 51years respectively while the overall mean age was 49 years.

Table 1: Socio-economic and Housing Attributes of Residents

\begin{tabular}{|c|c|c|c|}
\hline Attributes & Ibadan & Akure & Total \\
\hline & Frequency (\%) & Frequency (\%) & Frequency (\%) \\
\hline \multicolumn{4}{|l|}{ Gender } \\
\hline Male & $23(41.8 \%)$ & $33(64.7 \%)$ & $56(52.8 \%)$ \\
\hline Female & $32(58.2 \%)$ & $18(35.3 \%)$ & $50(47.2 \%)$ \\
\hline Total & $55(100.0 \%)$ & $51(100.0 \%)$ & $106(100.0 \%)$ \\
\hline \multicolumn{4}{|l|}{ Age } \\
\hline$\leq 20$ & $6(10.9 \%)$ & $0(0.0 \%)$ & $6(5.7 \%)$ \\
\hline $20-60$ & $39(70.9 \%)$ & $40(78.4 \%)$ & $79(74.5 \%)$ \\
\hline$\geq 61$ & $10(18.2 \%)$ & $11(21.6 \%)$ & $21(19.8 \%)$ \\
\hline Total & $55(100.0 \%)$ & $51(100.0 \%)$ & $106(100.0 \%)$ \\
\hline \multicolumn{4}{|c|}{ Educational Attainment } \\
\hline Primary & $12(21.8 \%)$ & $14(27.4 \%)$ & $26(24.5 \%)$ \\
\hline Secondary & $22(40.0 \%)$ & $6(11.7 \%)$ & $28(26.4 \%)$ \\
\hline Tertiary & $21(38.2 \%)$ & $31(60.9 \%)$ & $52(49.1 \%)$ \\
\hline Total & $55(100.0 \%)$ & $51(100.0 \%)$ & $106(100.0 \%)$ \\
\hline \multicolumn{4}{|c|}{ Average Monthly Income } \\
\hline$\leq \neq 20,000$ & $11(29.7 \%)$ & $4(11.4 \%)$ & $15(20.8 \%)$ \\
\hline $21,000-\$ 60,000$ & $16(43.2 \%)$ & $13(37.1 \%)$ & $29(40.3 \%)$ \\
\hline$\geq \$ 1,000$ & $10(27.0 \%)$ & $18(51.4 \%)$ & $28(38.9 \%)$ \\
\hline Total & $\star 37(100.0 \%)$ & $\star 35(100.0 \%)$ & $\star 72(100.0 \%)$ \\
\hline \multicolumn{4}{|c|}{ Number of Years Spent in the Study Area } \\
\hline$\leq 10$ years & $7(12.7 \%)$ & $10(19.6 \%)$ & $17(16.0 \%)$ \\
\hline $11-20$ years & $40(72.7 \%)$ & $26(51.0 \%)$ & $66(62.3 \%)$ \\
\hline$\geq 20$ years & $8(14.6 \%)$ & $15(29.4 \%)$ & $23(21.7 \%)$ \\
\hline Total & $55(100.0 \%)$ & $51(100.0 \%)$ & $106(100.0 \%)$ \\
\hline \multicolumn{4}{|l|}{ Type of Residents } \\
\hline Tenants & $19(34.5 \%)$ & $24(47.1 \%)$ & $43(40.6 \%)$ \\
\hline Landlords & $36(65.5 \%)$ & $27(52.9 \%)$ & $63(59.4 \%)$ \\
\hline Total & $55(100.0 \%)$ & $51(100.0 \%)$ & $106(100.0 \%)$ \\
\hline
\end{tabular}

*This was less than the total number of respondents as some respondents refused to declare their monthly income.

As stated by Olofsson and Öhman, (2006) and Owoeye and Adedeji, (2003) that level of education influences awareness. Thus, residents' level of educational attainments across the two cities could serve as the basis for assessment of the perception of the residents on the development control activities in the study area. Findings on residents' educational qualifications in Ibadan revealed that $21.8 \%, 40.0 \%$ and $38.2 \%$ of the residents in the city had primary, secondary and tertiary education respectively while in Akure, findings revealed that $27.4 \%$ of the residents had primary education, $11.7 \%$ had secondary education while the remaining majority $(60.9 \%)$ had tertiary education. 
For easy analysis, the initial quantitative data on residents' average monthly income were grouped into three: low, medium and high. Income below $\$ 20,000$ categorised as low income. The reason is that the minimum wage at the federal level in Nigeria is $\$ 18,000$ while it ranges from $\$ 15,000$ to $\$ 20,000$ in the states of the federation (Afon, 2011; Daramola, 2015). The medium monthly income was categorised from $\$ 20,000$ to $\$ 60,000$ while residents earning above $\$ 60,000$ were categorised as high income earners. Based on the categorisation, variation in income class existed across the two capital cities as presented in Table 1. Further findings on the average monthly income in Ibadan revealed the $29.7 \%$ of the respondents earned less than $\$ 20,000,43.3 \%$ earned between $\$ 21,000$ - $\$ 60,000$ while $27.0 \%$ earned above $\$ 61,000$. The mean monthly income in Ibadan was $\$ 51,355$. In Akure $11.4 \%$, $37.1 \%$ and $51.4 \%$ of the respondents earned less than $\$ 20,000$, between $\$ 21,000$ - $\$ 60,000$, and above $\$ 61,000$ respectively. The mean monthly income in Akure was $\$ 49,780$.

Other identifiable parameters in relation to development control activities are number of years spent in the study area. Studies such as Brown and Raymond (2007) and Olowoporoku (2017b) postulated that environmental concern is a function of length of residence. This is because the longer the period people live in an area; the more they are likely to understand the problems associated with the environment. Findings revealed that majority $(87.3 \%)$ had spent more than 10 years residing in the Ibadan while in Akure $80.4 \%$ of the respondents had spent more than 10 years in the city.

Investigation was also made into the type residents to know whether the house were owner-occupier or rented. The essence of this variable is that the ownership or otherwise of the house occupied by a resident can determine his knowledge about development control activities. In Ibadan, $65.5 \%$ of the residents sampled were owners of the houses they occupied while $34.5 \%$ rented their houses. In Akure, $47.1 \%$ of the sampled residents were tenants; the remaining $52.9 \%$ were landlords.

\subsection{Residents' Awareness of Development Control Activities}

Findings were made into the source of awareness of development control activities in the study areas. This is as contained in Table 2. Residents were allowed to select more than one option as an individual can be aware through more than one source at a time. Investigation from Ibadan revealed that demolition exercise, building collapse and mass media were the three prominent sources of awareness and they accounted for $22.5 \%, 21.1 \%$ and $16.9 \%$ of the respondents respectively. Findings from Akure revealed that demolition exercise $(21.5 \%)$, period of building collapse $(20.0 \%)$ and contravention notices $(16.1 \%)$ were the prevalent means of awareness of residents about development control activities in the city.

Table 2: Residents Source of Awareness on Development Control Activities

\begin{tabular}{|c|c|c|c|}
\hline Sources & Ibadan & Akure & Total \\
\hline Source of Awareness & Frequency (\%) & Frequency (\%) & Frequency (\%) \\
\hline Demolition exercise & $48(22.5 \%)$ & $44(21.5 \%)$ & $92(22.0 \%)$ \\
\hline Building collapse & $45(21.1 \%)$ & $41(20.0 \%)$ & $86(20.6 \%)$ \\
\hline Mass media & $36(16.9 \%)$ & $33(16.1 \%)$ & $69(16.5 \%)$ \\
\hline Contravention notices & $33(15.5 \%)$ & $29(14.1 \%)$ & $62(14.8 \%)$ \\
\hline Building approval process & $21(9.9 \%)$ & $20(9.8 \%)$ & $41(9.8 \%)$ \\
\hline Family/friends & $17(8.0 \%)$ & $22(10.7 \%)$ & $39(9.3 \%)$ \\
\hline Billboard/Posters & $13(6.1 \%)$ & $16(7.8 \%)$ & $29(6.9 \%)$ \\
\hline Total & *213 (100.0\%) & *205 $(100.0 \%)$ & * $418(100.0 \%)$ \\
\hline
\end{tabular}

*This was more than the total number of questionnaire because respondents selected more than one option

Table 3 shows residents' view of the function of development control agencies. This is measured in the study by calculating Residents' Agreement Indices (RAI). The RAI across the two cities are measured by mean and standard deviation. Computed average RAI for the Ibadan and Akure were 3.142 and 3.140 respectively. 
Table 3: Residents' Agreement Indices (RAI) with functions of Development Control Agencies in the Study Area

\begin{tabular}{|c|c|c|c|c|c|c|}
\hline Residents' Agreement & \multicolumn{3}{|c|}{ Ibadan } & \multicolumn{3}{|c|}{ Akure } \\
\hline Granting of planning permit & 4.304 & 1.162 & 2nd & 3.198 & 0.058 & 7 th \\
\hline Formulation of physical development policies & 3.360 & 0.218 & 6 th & 3.446 & 0.147 & 4 th \\
\hline Controlling of physical development activities & 3.432 & 0.290 & 4th & 3.485 & 0.186 & $1 \mathrm{st}$ \\
\hline Selection and designing of open spaces & 3.390 & 0.248 & 5 th & 3.406 & 0.266 & 5 th \\
\hline Opening up of roads & 3.532 & 0.390 & $3 \mathrm{rd}$ & 3.079 & -0.061 & 9 th \\
\hline Granting of fence permit & 3.218 & 0.076 & 8th & 2.871 & -0.269 & 12 th \\
\hline Settlement of disputes on land ownership & 3.218 & 0.076 & 8th & 2.644 & -0.496 & 13th \\
\hline Taking part in street naming & 3.320 & 0.178 & 7 th & 3.069 & -0.071 & 10th \\
\hline Declaring some roads as one way traffic & 2.964 & -0.178 & 9th & 3.069 & -0.071 & 10th \\
\hline Analysis of Variables & Ibadan & Akure & & & & \\
\hline Mean RSI & 3.142 & 3.140 & & & & \\
\hline Standard Deviation (SD) & 0.243 & 0.269 & & & & \\
\hline Coefficient of Variation & $7.8 \%$ & $8.7 \%$ & & & & \\
\hline
\end{tabular}

The study revealed that residents in the Ibadan agreed that development control agencies grant planning permits as it ranked first. In Akure, there was a different opinion as residents ranked control physical development activities first among the role of development control agencies. The calculated highest means values in the Ibadan and Akure were 4.376 (preparation of development plans) and 3.485 (control of physical development activities) respectively.

Residents' in the Ibadan disagreed that development control functions include declaring city section special planning areas as it ranked the lowest and rated 2.742. In Akure, residents disagreed that development control agencies' function includes settlement of disputes on land ownership and declaring city section special planning areas. These received the lowest ratings Akure with computed means of 2.641. From the foregoing analysis in the table 3, it can be deduced that respondents in the two cities have different perception of the function of development control agencies. The standard deviation (SD) for Ibadan and Akure 0.243 and 0.269 respectively. The SD was very helpful in computing the CV for each of the towns which was $7.8 \%$ and $8.7 \%$ respectively. This implied that $92.2 \%$, and $91.3 \%$ of the resident agreement indexes for Ibadan and Akure clustered around the mean resident agreement indexes that was computed for the respective towns. With the higher proportions of CVs of the dataset obtained from these towns, it could be inferred that the computed $\overline{\mathrm{RAI}}$ were very much reliable.

Presented in Table 4 are responses of residents with satisfaction with the various development control activities. Computed average Resident Satisfaction Index (RSI) in Ibadan and Akure were 3.333 and 3.258. Findings revealed that residents in the Ibadan were satisfied with education and enlightenment programme and settlement of disputes and as both ranked first and second with a rating of 4.304 and 4.376 respectively in the city. Residents in the Akure were satisfied with period of granting approval to proposed plans and public involvement in decision making as they rated them 3.609 and 3.594 respectively. Residents of Ibadan were dissatisfied with timely action on contravention and public involvement in decision making as they ranked lowest with mean values 2.742 and 2.852 respectively. In Akure the residents were unsatisfied with the timely action on contravention notice and politeness of development control officers as they rated 2.797 and 2.942 respectively. 
Table 4: Residents' Satisfaction Indices (RSI) with Development Control Activities

\begin{tabular}{|c|c|c|c|c|c|c|}
\hline \multirow{2}{*}{ Residents' Satisfaction } & \multicolumn{3}{|c|}{ Ibadan } & \multicolumn{3}{|c|}{ Akure } \\
\hline & RSI & $\overline{\mathrm{RAI}} \overline{\mathrm{RSI}}$ & Rank & RSI & RAI- $\overline{\mathrm{RSI}}$ & Rank \\
\hline Education and enlightenment programme & 4.376 & 1.043 & $1 \mathrm{st}$ & 3.203 & -0.055 & 5th \\
\hline Settlement of disputes & 4.304 & 0.971 & 2nd & 3.333 & 0.075 & 4th \\
\hline Dissemination of planning information & 3.532 & 0.199 & $3 \mathrm{rd}$ & 3.159 & -0.099 & 7th \\
\hline Enforcement of development control regulations & 3.390 & 0.057 & 4th & 3.174 & -0.084 & 6th \\
\hline Politeness of development control officer to developers & 2.964 & -0.369 & 5 th & 2.942 & -0.316 & 8th \\
\hline Period of granting approval to proposed plans & 2.954 & -0.379 & 6th & 3.609 & 0.351 & $1 \mathrm{st}$ \\
\hline Timely detection of contravention & 2.884 & -0.449 & 7th & 3.507 & 0.249 & $3 \mathrm{rd}$ \\
\hline Public involvement in decision making & 2.852 & -0.481 & 8 th & 3.594 & 0.336 & 2nd \\
\hline Timely action on contravention & 2.742 & -0.591 & 9th & 2.797 & -0.461 & 9th \\
\hline Analysis of Variables & Ibadan & Akure & & & & \\
\hline Mean RSI & 3.333 & 3.258 & & & & \\
\hline Standard Deviation (SD) & 0.626 & 0.282 & & & & \\
\hline Coefficient of Variation & $18.7 \%$ & $8.7 \%$ & & & & \\
\hline
\end{tabular}

From the foregoing analysis in the table 4, it can be deduced that in the residents in the two cities are at variance with satisfaction with development control activities across the two cities. The standard deviation (SD) for Ibadan and Akure 0.626 and 0.282 respectively. The SD was very helpful in computing the $\mathrm{CV}$ for each of the towns which were $18.7 \%$ and $8.7 \%$ respectively. This implied that $81.3 \%$, and $91.3 \%$ of the resident agreement indexes for Ibadan and Akure clustered around the mean resident satisfaction indexes that were computed for the respective towns. With the higher proportions of CVs of the dataset obtained from these towns, it could be inferred that the computed $\overline{\mathrm{RSI}}$ sere very much reliable.

\subsection{Residents' Response to Development Control Activities}

Information on residents' response to development control activities is as presented in Table 5. Starting with availability of survey plans, findings on Ibadan and Akure revealed that majority $(67.3 \%)$ and (58.8\%) of the residents do not have survey plans. Further findings were made into the reasons why resident do not have survey plans. In Ibadan $29.7 \%$ of the residents claimed the cost of survey plan was high while the majority $(70.3 \%$ ) claimed survey plan was not compulsory in the construction process. In Akure, $40.0 \%$ of the residents claimed high cost of obtaining survey plan was the reason for them not to obtain survey plans while $60 \%$ of the respondents' claimed survey plan was not compulsory in the construction process.

Investigation was made to determine if residents prepared building plans before construction of buildings. In Ibadan, it was discovered the proportion of the residents that did not prepare building plans before construction were $76.4 \%$ while the remaining $23.6 \%$ prepared building plans before construction. In the Akure, $70.6 \% \%$ of the residents did not prepare building plans before construction of their buildings while $29.4 \%$ of the respondents prepared building plans before construction. On the reason for not preparing building plans before construction majority, $70.9 \%$ of the residents in Ibadan claimed preparing building plan was an additional cost to cost of construction while in Akure, 56.9\% of the residents opined that building plans increase the cost of construction in the study area.

On approval of buildings before construction, in Ibadan $87.8 \%$ of the residents did not get approval before construction while in Akure 78.4\% of the residents did not obtain approval before construction of their buildings. Findings on reasons for not taking approval before building houses in Ibadan revealed that $46.7 \%$ of the residents claimed planning approval was costly while $53.4 \%$ claimed that taking approval for building was time consuming. In Akure, $41.8 \%$ claimed planning approval is costly while $58.2 \%$ claimed planning approval is time consuming.

In Ibadan a little more than half (66.7\%) collected approval through middlemen, $16.7 \%$ collected approval through architects while the remaining $16.7 \%$ collected approval through town planners. In 
Akure, $36.4 \%$ of the residents collected approval through middlemen and $36.4 \%$ collected approval through town planners.

Table 5: Residents' response to Development Control Activities

\begin{tabular}{|c|c|c|c|}
\hline Activities & Ibadan & Akure & Total \\
\hline & Frequency $(\%)$ & Frequency $(\%)$ & Frequency $(\%)$ \\
\hline \multicolumn{4}{|c|}{ Availability of Survey Plans } \\
\hline Yes & $18(32.7 \%)$ & $21(41.2 \%)$ & $39(36.8 \%)$ \\
\hline No & $37(67.3 \%)$ & $30(58.8 \%)$ & $67(63.2 \%)$ \\
\hline Total & $55(100.0 \%)$ & $51(100.0 \%)$ & $106(100.0 \%)$ \\
\hline \multicolumn{4}{|c|}{ Reasons for No Survey Plans } \\
\hline High cost & $11(29.7 \%)$ & $12(40.0 \%)$ & $23(34.4 \%)$ \\
\hline Not Compulsory & $26(70.3 \%)$ & $18(60.0 \%)$ & $44(65.6 \%)$ \\
\hline Total & $37(100.0 \%)$ & $30(100.0 \%)$ & $67(100.0 \%)$ \\
\hline \multicolumn{4}{|c|}{ Preparation of Building Plan Before Construction } \\
\hline Yes & $13(23.6 \%)$ & $15(29.4 \%)$ & $28(26.4 \%)$ \\
\hline No & $42(76.4 \%)$ & $36(70.6 \%)$ & $78(73.6 \%)$ \\
\hline Total & $55(100.0 \%)$ & $51(100.0 \%)$ & $106(100.0 \%)$ \\
\hline \multicolumn{4}{|c|}{ Reasons for Not Preparing Building Plan Before Construction } \\
\hline Building cost Addition & $39(70.9 \%)$ & $29(56.9 \%)$ & $68(64.2 \%)$ \\
\hline Not necessary & $16(29.1 \%)$ & $22(43.1 \%)$ & $38(35.8 \%)$ \\
\hline Total & $55(100.0 \%)$ & $51(100.0 \%)$ & $106(100.0 \%)$ \\
\hline \multicolumn{4}{|c|}{ Obtainment of Approval Before Embarking on Any Construction } \\
\hline Yes & $6(12.2 \%)$ & $11(21.6 \%)$ & $17(16.0 \%)$ \\
\hline No & $49(87.8 \%)$ & $40(78.4 \%)$ & $89(84.0 \%)$ \\
\hline Total & $55(100.0 \%)$ & $51(100.0 \%)$ & $106(100.0 \%)$ \\
\hline \multicolumn{4}{|c|}{ Reason for Not Taking Approval } \\
\hline Planning Approval Costly & $42(46.7 \%)$ & $33(41.8 \%)$ & $75(45.7 \%)$ \\
\hline Time Consuming & $48(53.4 \%)$ & $46(58.2 \%)$ & $94(54.3 \%)$ \\
\hline Total & $90(100.0 \%)$ & $79(100.0 \%)$ & $169(100.0 \%)$ \\
\hline \multicolumn{4}{|c|}{ Means of Collection of Approval } \\
\hline Contract to Architect & $1(16.7 \%$ & $2(18.1 \%)$ & $2(11.7 \%)$ \\
\hline Contact to Town Planner & $1(16.7 \%)$ & $4(36.4 \%)$ & $5(29.4 \%)$ \\
\hline By Oneself & $0(0.0 \%)$ & $1(9.1 \%)$ & $1(5.9 \%)$ \\
\hline Middlemen & $4(66.7 \%)$ & $4(36.4 \%)$ & $8(47.0 \%)$ \\
\hline Total & $6(100.0 \%)$ & $11(100.0 \%)$ & $17(100.0 \%)$ \\
\hline
\end{tabular}

\subsection{Conclusions}

The importance of examining the residents' perception on development control activities is based on the significance of the roles of residents in the success of any government enterprise. Also, the satisfaction that the residents derive from the activity will serve as a motivating factor for their participation in the programme. From the findings above, the following are observable. Generally, residents were aware of development control activities across the two cities. However, there were differences in residents' perception of development control agencies and satisfaction with the development control activities, as a result of differences in the way development control agencies carry out their duties and residents' socioeconomic characteristics.

Majority of the residents got aware of development control activities via building collapse and demolition exercise. The outcome of the study revealed that residents in Ibadan agreed that development control agencies are solely responsible for grant planning permits while residents in Akure agreed that the main duty of development control agencies are to regulate physical development activities. These identified activities are the core of development control agencies. The study established the divergent views on satisfaction with conduct of development control activities in the study area. In Ibadan, residents reflected their dissatisfaction with timely action on contraventions, while residents in Akure rated the politeness of development control officers to developers poorly. This low level of satisfaction towards the conduct of the activity can trigger residents' apathy towards development control in the 
study area. Based on these, the followings are recommended on development control activities in the study area.

There should be a reduction in the cost of procuring building permits also the bottlenecks involved in the process should be reduced in order to aid easy access to building permits. There should be proper awareness to the residents about the benefits of development control activities in the study area. The development control agencies should cultivate a cordial relationship with the residents so as not scare people from fulfilling their roles during the building approval period. Public campaign through the use of mass media and bill boards should be employed in order to spread the gospel of development control to residents of the two cities and other cities with similar background.

\section{References}

Adeyeye, L. A. (2010). Understanding Development Control and Settlement of Disputes. Published by Timade Venture Shop F3 extension Ife Central LGA Shopping Complex Ile Ife.

Adeyemi, S. A. (2015). Development Control Practices in South Western Nigeria. A Ph.D. Proposal Thesis Submitted to the Department of Urban and Regional Planning, Obafemi Awolwo University Ile-Ife, Nigeria.

Afon, A. O (2011).Residential Differentials in Behavoiur and Environmental Hazards and Risks Perception in Ile-Ife Nigeria. In: A.O Afon and O.O Aina (eds): Issues in the Built Environment of Nigeria: 52-80.

Afon, and Faniran, (2013). Intra- Urban Citizen Participation in Monthly Environmental Sanitation in Nigeria; The Ibadan Experience. Journal of applied Sciences in Environmental Sanitation, 8 (1): 1-10.

Afon, A. O., Abolade O., and Okanlawon, S. A. (2006). Users' Perception of Environmental Hazards and Risks as a Tool in Public Space Management: The Case of Selected Motor Parks in Lagos, Nigeria. A Paper Presented at the 5th FIG Regional Conference on Promoting Land Administration and Good Governance, Accra, Ghana, March 8-14.

Agbola, T. (2007). Physical planning in Nigeria since Independence. A Performance Narrative. Journal of Institute of Town Planners 10 (1).

Aluko, O. E. (2010). The Impact of Urbanization on Housing Development: The Lagos Experience. Ethopian Journal of Environmental Studies and Management 3 (3).

Amujiri, B.A. (2001), 'Urban Planning in Nigeria; Problems and Remedies'. In Ezeani and Elekwa (eds).Issues in Urbanization and Urban Administration in Nigeria. Nsukka: Jamoe Enterprises.

Alabi, M. O. (2010). Priotizing Factors of Failure in Controlling Physical Development inNigerian Cities. Journal of Sustainable Development 12 (2): 215-231.

Aribigbola, A. (2008). Improving Urban Land Use Management in Nigeria. The Case of Akure. Theoretical and Empirical Researches in Urban Management 3 (9).

Bhatta, B. (2010). Analysis of Urban Growth and Sprawl from Remote Sensing Data. Available at http://www.springer.com/978-3-642-05298-9

Brown, G and Raymond, C. (2007). The relationship between place attachment and landscape values: Toward mapping place attachment. Applied Geography 27, 89-111.

Daramola, O. P. (2015). Environmental Sanitation Practices in Residential Areas of Ibadan Metropolis. A Thesis Submitted in Partial Fulfilment of the Requirement for the Award of Doctor of Philosophy 
Degree in the Department of Urban And Regional Planning, Obafemi Awolowo University, Ile-Ife, Nigeria.

Daramola, O. P. and Olowoporoku, O. A. (2016). Environmental Sanitation Practices in Osogbo, Nigeria: An Assessment of Residents' Sprucing-Up of their Living Environment. Journal of Economic and Environmental Studies Opole University Poland 16 (4): 699-716.

Fakere, A. A., Fadairo, G. and Oriye, O. (2012). Domestic Waste Management and Urban Residential Environment: Focus on Akure, Nigeria. International Journal of Engineering and Technology 2 (5): 878- 887 .

Kawu, A. M., Ahmed, A. and Usman, A. S. (2012). Learning from Tradition: Elements and Practice of Urban Development Control in Zaria City, Nigeria. American International Journal of Contemporary Research 2 (7): 205-213.

Kio-Lawanson, D., Duru, M. N., John, B. D. and Eebee, A. L. (2016). The Challenge of Development Control in Nigerian Capital Cities- A Case of Some Selected Cities in the Niger Delta.iiste 6 (2): 148-156.

Lamond J., Awuah B. K., Lewis E., Bloch R., and Falade B. J. (2015). Urban Land, Planning and Governance Systems in Nigeria. Urbanisation Research Nigeria (URN) Research Report. London: ICF International. Creative Commons Attribution-Non-Commercial Share Alike CC BY-NC SA

Obabori, A. O., Obiwuevi, D. B. and Olomu, J. I. (2007). Development Control, an Important Regulator of Settlement Growth. A Case Study of Ekpoma Nigeria. Journal of Human Ecology, 21 (4): 285-291.

Odunsi, O. (2016). Students' Perception of Environmental Hazards and Risks in Selected Public Tertiary Educational Institutions in Oyo State, Nigeria. MSc Project, Department of Urban and Regional Planning, Obafemi Awolowo University, Ile-Ife, Nigeria.

Oduwaye, (2004). Violating Building Plan Registration in Ikeja, Lagos, Nigeria, Ife Planning Journal, Journal of Ife Community Development Study Team (ICOM DEST).

Ogundele, F. O., Ayo, O., Odewumi, S. G., Aigbe, G. O. (2011). Challenges and Prospects of Physical Planning Development Control. A Case Study of Festac Town, Lagos, Nigeria. African Journal of Political Science and International Relations. 5 (4): 174-178.

Olofsson, A. and Öhman, S. (2006). General Beliefs and Environmental Concern. Trans-Atlantic Comparisons. Environment and Behavior, 38 (6): 768-790.

Olotuah, A. O. (2010), Housing Development and Environmental Degeneration in Nigeria, The Built \& Human Environment Review, 3, 42 -48.

Olowoporoku, O. A. (2017a). Residents' Perception of Environmental Hazards and Risks in Coastal Towns of Delta State, Nigeria. MSc Thesis, Department of Urban and Regional Planning, Obafemi Awolowo University, Ile-Ife, Nigeria.

Olowoporoku, O. A. (2017b). Assessment of Household Disaster Management Literacy in Osogbo, Nigeria. A Paper Presented at the7th Environmental Design and Management International Conference (EDMIC) held at Obafemi AwolowoUniversity Ile Ife on May 22nd - $24^{\text {th }}$.

Olujimi, A. B. (2009). Evolving a Planners Strategy for Managing Urban Sprawl in Nigeria. Journal of Human Ecology 25 (3): 201-208. 
Olujimi, J. A. and Fashuyi, O. S. (2004). Anatomy of Illegal Structures in Akure Metropolis, Ondo State. Journal of Nigerian Institute of Town Planners 27: 79-95

Omisore, E. O. and Akande, C. G. (2004). A Coordinated Approach to Solving Physical Planning Problems at the Local Level: A Case of Ogbomosho Region of Oyo State. A Paper Presented at the $35^{\text {th }}$ Annual Conference of Nigerian Institute of Town Planners, Theme: Physical Planning Standards and Environmental Management $6^{\text {th }} 8^{\text {th }}$ October

Owoeye, J. O. and Adedeji, Y. M. D. (2003). Poverty, Sanitation and Public Health Nexus Implications on Core Residential Neighbourhood of Akure, Nigeria. International Journal of Developing Societies 2 (3): 96-104.

Owoeye, J. O and Ibitoye A. O. (2016). Analysis of Akure Urban Land Use Change Detection from Remote Imagery Perspective. Urban Studies Research, 16(1): 1-10

Oyelade, T. O. (2012). Appraisal of Development Control Activities in the Peri-Urban Areas of Osogbo Metropolis, Nigeria. M.Sc. Project, Department of Urban and Regional Planning, Obafemi Awolwo University Ile-Ife, Nigeria.

Oyelayo, A. (2014). Environmental Sanitation Practices of Sellers and Patrons in Aleshinloye and Bodija Markets, Ibadan. BSc Project, Department of Urban and Regional Planning, Obafemi Awolowo University Ile-Ife, Nigeria

Sanusi, Y. A. (2006). An Assesment of the Relationship between Poverty and Environmental Quality in Minna Metropolis, Niger State. PhD Thesis, Post Graduate School, Federal University of Technology Minna.

Ujoh, F. K. and Ifatimehin, O. O.( 2010). Understanding Urban Sprawl in Federal Capital City Abuja. Towards a Sustainable Urbanization in Nigeria. Journal of Geography and Regional Planning, 3 (5): 106-113.

UN-HABITAT (2009). Planning Sustainable Cities: Global Reports on Human Settlements 2009. United Nations Human Settlement Programme. http.www.unhabitat.org

UN-HABITAT (2016). World Cities Report/ Urbanization and Development: Emerging Futures.

Vivan, E. L., Kyom, B. C. and Balasom, M. K. (2013). The Nature, Scope and Dimensions of Development Control, Tools and Machineries in Urban Planning In Nigeria. International Journal of Innovative Environmental Studies Research 1 (1):48-54 